\title{
Does crop succession and nitrogen splitting fertilization change the technological quality of common bean?
}

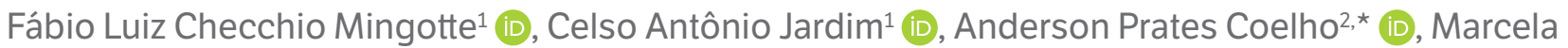 \\ Midori Yada ${ }^{1}$ (D), Fábio Tiraboschi Leal ${ }^{1}$ (D), Leandro Borges Lemos ${ }^{1}$ (D), Domingos Fornasieri Filho ${ }^{1}$ (D) \\ 1. Universidade Estadual Paulista “Júlio de Mesquita Filho" - Faculdade de Ciências Agrárias e Veterinárias - Departamento de Ciências da \\ Produção Agrícola - Jaboticabal (SP), Brazil. \\ 2. Universidade Estadual Paulista “Júlio de Mesquita Filho” - Faculdade de Ciências Agrárias e Veterinárias - Departamento de Engenharia e \\ Ciências Exatas - Jaboticabal (SP), Brazil. \\ Received: Dec. 26, 2020 | Accepted: Jul. 1, 2021 \\ Section Editor: Osvaldo Guedes Filho \\ *Corresponding author: anderson_100ssp@hotmail.com \\ How to cite: Mingotte, F. L. C., Jardim, C. A., Coelho, A. P., Marcela, M. Y., Leal, F. T., Lemos, L. B. and Fornasieri Filho, D. (2021) Does crop \\ succession and nitrogen splitting fertilization change the technological quality of common bean? Bragantia, 80, e4521. https://doi. \\ org/10.1590/1678-4499.20200525
}

\begin{abstract}
The crop succession and nitrogen splitting fertilization are managements that can affect the common bean technological quality and, consequently, the profitability of producer and the food biological value. The aim of this study was to evaluate whether crop succession and $\mathrm{N}$ splitting fertilization promote differences in the technological quality of common bean grains. The experiment was carried out during winter over two agricultural years in southeastern Brazil. A randomized block design was used in a split-plot scheme, with four replications. The plots were composed of three crop successional systems (maize sole, maize + Urochloa ruziziensis, U. ruziziensis sole) and the subplots contained nine combinations of $\mathrm{N}$ splitting fertilization at a rate of $90 \mathrm{~kg} \cdot \mathrm{ha}^{-1} \mathrm{~N}$ top-dressing in the phenological stages $\mathrm{V}_{3}, \mathrm{~V}_{4}$, and $\mathrm{R}_{5}$ of the common bean and a control without fertilization. The evaluated variables were: sieve yield greater than or equal to 12 ( $S Y \geq 12$ ), crude protein content, cooking time, and hydration ratio. Crop succession promotes differences in the technological quality of common bean; however, the $\mathrm{N}$ splitting fertilization did not change the technological attributes of grains. The highest technological quality of common bean was obtained after succession with $U$. ruziziensis sole, generating large size and crude protein content of grain, followed by the succession with maize $+U$. ruziziensis intercropping, and finally, the succession with maize sole. Therefore, the crop succession is a fundamental factor for obtaining common bean with higher technological quality, affecting the food biological value and the profitability of producers.
\end{abstract}

Key words: Phaseolus vulgaris L.; intercropping; sieve yield; crude protein content; cooking time.

\section{INTRODUCTION}

Common bean (Phaseolus vulgaris L.), being one of the most relevant protein sources for the poorest population of underdeveloped and developing countries (Fageria et al. 2014), has high social and economic importance worldwide. In addition to a high amount of protein, common bean grains still have significant amounts of carbohydrates, essential amino acids for humans and vitamins, and are a food used to improve world food security (Miano et al. 2018; Nassary et al. 2020). In Brazil, common beans are grown annually and they occupy an area of 1.6 million hectares, generating a gross production value of $\mathrm{R} \$ 12.5$ billion for Brazilian agribusiness (Brazil 2020; Conab 2020).

Besides grain yield, the profit of the common bean producer is associated with grain technological quality, since the product price is also defined based on grain technological attributes (Carbonell et al. 2010). Among the factors that define the price of common beans of commercial group 'Carioca', the size and tegument color can be highlighted. This is because the larger and lighter the grains, the higher the price paid per kilogram of grains (Carbonell et al. 2010; Ramalho and Abreu 2006). 
Due to changes in the lifestyle of people, household consumption of common bean per capita in Brazil has decreased, from $12.4 \mathrm{~kg} \cdot$ inhabitant ${ }^{-1} \cdot \mathrm{year}^{-1}$ in 2003 to $5.9 \mathrm{~kg} \cdot$ inhabitant $^{-1} \cdot \mathrm{year}^{-1}$ in 2018 , causing a $52 \%$ reduction (IBGE 2020). This reduction in the common bean consumption can affect food security, since common bean is a low-cost food, accessible to the population and nutritionally rich in proteins, vitamins, and minerals. In this sense, improving grain quality is relevant mainly to market price and consumer acceptance, in addition to promoting greater food security.

Several studies have evaluated the effects of agricultural management on the technological quality of common bean, with emphasis on fertilization, soil preparation, and irrigation systems (Aires et al. 2019; Flôres et al. 2017; Soratto et al. 2014). However, little is known about the effect of crop succession on common bean quality. In Brazil, common bean is grown in many different production systems, highlighting cultivation after grasses, such as maize. To avoid successive maize crops in the same area over the years, some producers have adopted the cultivation of forage crops (palisade grass and Congo grass) before sowing common bean. This helps to reduce nematode populations, diseases, and pests, in addition to promoting a better soil structure and greater quantity of straw for the installation and maintenance of no-till systems. However, even with the many benefits of using forage grasses in agroecosystems (Gopalakrishnan et al. 2009), many producers do not adopt this practice because of lack of direct financial returns. Thus, the evaluations of crops succession on the quality of common bean can provide subsidies for the use of species of the genus Urochloa in the agricultural system and may promote economic and nutritional benefits for the cultivation of common bean.

The high amount of straw produced by grasses grown prior to cultivation of common bean has several benefits, including nutrient availability, reduction of water loss through evaporation, and improvements in soil structure (Mingotte et al. 2020; Soratto et al. 2014). However, the high amount of straw on the surface may promote soil nitrogen immobilization, which can cause deficiency of this nutrient in phenological stages with greater demand by common bean, which directly affects grain yield and quality (Soratto et al. 2014). Thus, $\mathrm{N}$ fertilization management strategies, such as splitting indicated rates, can supply the nutrient demand of crop avoiding deficiencies, which can promote differences in the quality of the crop grains.

The hypothesis tested in this study was that crop succession and $\mathrm{N}$ splitting fertilization in top-dressing promote differences in the technological quality of common bean. The aim of this study was to evaluate whether crop succession and $\mathrm{N}$ splitting fertilization promote differences in the technological quality of common bean.

\section{METHODS}

The experiment was conducted at São Paulo State University (Unesp), School of Agricultural and Veterinarian Sciences, Jaboticabal, São Paulo, in the winter season of the years 2012 and 2013. The experimental area is located close to the coordinates of latitude $21^{\circ} 14^{\prime} 33^{\prime \prime}$ S, longitude $48^{\circ} 17^{\prime} 40^{\prime \prime}$ W, and has an average altitude of $565 \mathrm{~m}$. According to the Köppen climate classification, the climate of the region is tropical wet-dry (Aw), with rainy season in summer and dry winter, and the average annual rainfall in this region is $1,425 \mathrm{~mm}$ (Alvares et al. 2013). The soil is classified as eutrophic Red Latosol (Ustic Oxisol) with a clay texture, presenting $533 \mathrm{~g} \cdot \mathrm{kg}^{-1}$ of clay, $193 \mathrm{~g} \cdot \mathrm{kg}^{-1}$ of silt, and $274 \mathrm{~g} \cdot \mathrm{kg}^{-1}$ of sand.

Historically, the soil in this area was previously cultivated with annual crops (maize, common bean, soybean, and rice) for at least 15 years under a conventional soil management system that was implemented in the 2009/2010 agricultural year under the no-tillage system (NT). For NT installation, conventional soil tillage was carried out in August 2009 with soil chiseling, followed by plowing with disc plows and two leveling harrows and, subsequently, three crop succession systems containing maize and Urochloa ruziziensis in sole and intercropping were grown, prior to planting of common bean.

After conventional soil tillage for the implantation of the NT system, the experimental area was cultivated with the crop succession systems maize sole, maize $+U$. ruziziensis and $U$. ruziziensis sole. The sowing of these three crop succession systems was in December 2009. From then on, always in the NT system, in the same plots and in the same experimental area, the study was conducted with the three crop succession systems (maize sole, maize + U. ruziziensis and U. ruziziensis sole) and with the $\mathrm{N}$ splitting schemes in the common bean. In all years, the crop succession systems were sown between the months of November and January and the common bean in August. 
The experimental design was randomized blocks in a split-plot scheme, with 30 treatments. The treatments consisted of three crops succession and ten combinations of $\mathrm{N}$ splitting fertilization, with four replicates, totaling 120 experimental units.

The plots consisted of three crops succession containing maize sole, maize intercropped with U. ruziziensis, and U. ruziziensis sole, all preceding the sowing of common bean in August. The subplots consisted of nine combinations of $\mathrm{N}$ split fertilization, top-dressed using urea on common bean at $90 \mathrm{~kg} \cdot \mathrm{ha}^{-1} \mathrm{~N}$ rate (urea) and a control without fertilization. The fertilization was performed when the first trifolium fully expanded, when the third trifolium appeared and during preflowering period, that is, $\mathrm{V}_{3}, \mathrm{~V}_{4}$, and $\mathrm{R}_{5}$, respectively (Fernández et al. 1985). The $\mathrm{N}$ fertilizer splittings in common bean were $30+60+00,60+30+00,30+00+60,60+00+30,00+60+30,45+45+00,00+45+45,45+00+45$, and single rate in $\mathrm{V}_{4}(00+90+00)$ and absence of nutrient application in top-dressing $(00+00+00)$.

Each subplot composed of 10 rows of common bean, $5 \mathrm{~m}$ long, and the eight central rows were considered useful, with $0.5 \mathrm{~m}$ of each end freed. The applied rate of $\mathrm{N}$ in top-dressing $\left(90 \mathrm{~kg} \cdot \mathrm{ha}^{-1}\right.$ of $\left.\mathrm{N}\right)$ was based on high response class owing to irrigation and cultivation after grasses, following the recommendations of Ambrosano et al. (1997). As a source of $\mathrm{N}$ in topdressing, urea in a continuous fillet was applied $10 \mathrm{~cm}$ from the crop row. After fertilization, the area was irrigated with a $15 \mathrm{~mm}$ depth to incorporate the fertilizer into the soil.

The sowing of common bean was performed on August 18, 2012 and August 8, 2013. Before sowing in 2012, soil samples were collected to determine the chemicals properties in the $0.00-0.20 \mathrm{~m}$ layer. $\mathrm{pH}\left(\mathrm{CaCl}_{2}\right): 5.2$; organic matter $(\mathrm{OM})\left(\mathrm{g} \cdot \mathrm{dm}^{-3}\right): 22 ; \mathrm{P}$ resin $\left(\mathrm{mg} \cdot \mathrm{dm}^{-3}\right): 67 ; \mathrm{H}+\mathrm{Al}, \mathrm{K}, \mathrm{Ca}, \mathrm{Mg}$, sum of bases (SB) and cation exchange capacity (CEC) $\left(\mathrm{mmol}_{\mathrm{c}} \cdot \mathrm{dm}^{-3}\right)$ of $31.5,6.1,23.5,11,40.6$ and 72.1 , respectively, and $\mathrm{V}$ (base saturation): $56.5 \%$. Based on these results, it was decided to superficially apply $1.5 \mathrm{t} \cdot \mathrm{ha}^{-1}$ of dolomitic limestone with $90 \%$ relative total neutralizing power (RTNP). In the following year (2013), $\mathrm{pH}\left(\mathrm{CaCl}_{2}\right)$ was 5.3; $\mathrm{MO}\left(\mathrm{g} \cdot \mathrm{dm}^{-3}\right): 28 ; \mathrm{P}$ resin $\left(\mathrm{mg} \cdot \mathrm{dm}^{-3}\right): 126 ; \mathrm{H}+\mathrm{Al}, \mathrm{K}, \mathrm{Ca}, \mathrm{Mg}, \mathrm{SB}$ and CEC $\left(\mathrm{mmol}_{\mathrm{c}} \cdot \mathrm{dm}^{-3}\right)$ of $34,5.4,36,20,61.4$ and 95.4 , respectively, and $\mathrm{V}$ (base saturation): $64.0 \%$.

The cultivars used in 2012 and 2013 were 'Pérola' and 'IPR 139', respectively. In the two years, the sowing population was adjusted to 230,000 plants.ha ${ }^{-1}$, with a $0.45 \mathrm{~m}$ spacing between rows. The seeds were treated with carbendazim + thiram (45 and $105 \mathrm{~g}$ a.i. per $100 \mathrm{~kg}$ of seeds, respectively) and thiamethoxam (140 g a.i. per $100 \mathrm{~kg}$ of seeds). The sowing fertilization was $300 \mathrm{~kg} \cdot \mathrm{ha}^{-1}$ of the formulated 05-15-15. Common bean seeds were inoculated with Rhizhobium tropici liquid inoculant containing the strain SEMIA 4088, with concentration of $1 \times 10^{9} \mathrm{UFC} \cdot \mathrm{mL}^{-1}$. It was used the recommended dose of $250 \mathrm{~mL}$ for every $100 \mathrm{~kg}$ of seeds.

For both years, common bean emerged four days after sowing (DAS), with phenological stage $\mathrm{V}_{3}$ at 23 and 19 days after emergence (DAE), $V_{4}$ at 33 and $25 \mathrm{DAE}$, and $\mathrm{R}_{5}$ at 49 and $53 \mathrm{DAE}$, in 2012 and 2013, respectively. As it is a winter crop, the experiment was maintained under a conventional sprinkler irrigation management, with a 4-day watering shift, according to Allen et al. (1998). At 94 and 90 DAE, manual plucking of the plants present in the useful area in each subplot was carried out in 2012 and 2013, respectively, following a mechanized trail.

In 2012, the average maximum and minimum temperatures were 31.2 and $16.8^{\circ} \mathrm{C}$, respectively, with an accumulated rainfall of $198 \mathrm{~mm}$ (Fig. 1). In 2013, the average maximum and minimum temperatures were 29.0 and $15.4^{\circ} \mathrm{C}$, respectively, with an accumulated rainfall of $247 \mathrm{~mm}$.

After harvesting the common bean, in both years, the grain samples from each subplot were packed in paper bags and stored for 30 days at $25{ }^{\circ} \mathrm{C}$ and $40 \%$ relative humidity. After this period, the grain technological attributes were evaluated. To determine whether the sieve yield was greater than or equal to 12 ( $\mathrm{SY} \geq 12$ ), the samples were subjected to a $12 / 64$ " $\times 3 / 4(4.76 \times 19.05 \mathrm{~mm})$ sieve and agitated for $1 \mathrm{~min}$. The percentage of grains was calculated using the relationship between the weight of the grains retained in the sieve 12 and the total sample weight of each subplot.

To determine the crude protein content, cooking time, and hydration ratio of grains, the grains retained in the sieve 12 were used. To determine the crude protein content, the grains were dried in a forced air ventilation oven at $65^{\circ} \mathrm{C}$ until constant mass. After that, the grains were ground in Willey-type mill to determine $\mathrm{N}$ content. Crude protein content (CPC) was determined using Eq. 1 (AOAC 1995).

$$
\mathrm{CPC}=\text { total } \mathrm{N} \times 6.25
$$


where the total $\mathrm{N}$ represents the respective total $\mathrm{N}$ content in the grains from each subplot; the $\mathrm{N}$ was obtained using sulfuric digestion, according to Bataglia et al. (1983). The cooking time was determined using a modified Mattson cooker. This equipment consists of $25 \mathrm{vertical}$ stilettos, each weighing $90 \mathrm{~g}$ at the end, finished in a 1/16" diameter tip. The tip was supported on the grains during cooking, and, when the grain is cooked, the tip penetrates, displacing the stylet. The final cooking time of the sample was obtained when $50 \%+1$, that is, 13 stylets were displaced. To determine the cooking time, grains were hydrated with deionized water for a period of $12 \mathrm{~h}$, in proportion of $25 \mathrm{~g}$ of grains to $100 \mathrm{~mL}$ of deionized water, and during test, water temperature was maintained at $96^{\circ} \mathrm{C}$. The Proctor and Watts scale (1987) was adopted to verify the level of resistance to cooking, and the classifications are: very susceptible ( $<16 \mathrm{~min})$, medium susceptibility (16 to $20 \mathrm{~min}$ ), normal resistance (21 to $28 \mathrm{~min}$ ), medium resistance (29 to $32 \mathrm{~min}$ ), resistant (33 to $36 \mathrm{~min}$ ), and very resistant (> $36 \mathrm{~min})$ to cooking.
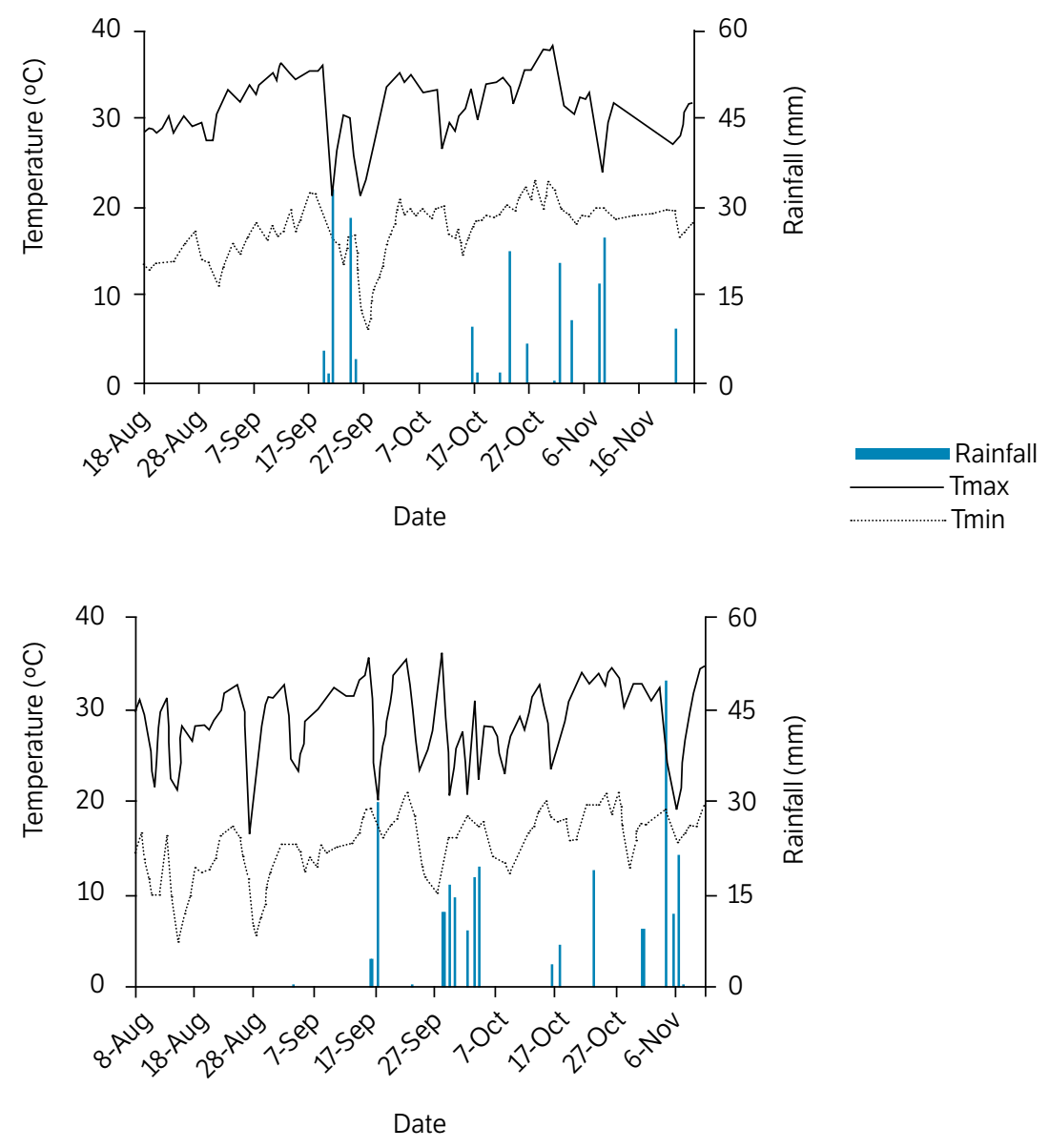

Figure 1. Daily climatic data of the agricultural years 2012 (a) and 2013 (b).

To determine hydration ratio (HR), a sample of $50 \mathrm{~g}$ of grains from each subplot was placed in plastic cups with $200 \mathrm{~mL}$ of deionized water and subjected to hydration for $12 \mathrm{~h}$. After that time, the water was drained, the grains were placed on absorbent paper for $10 \mathrm{~min}$, and the mass of the hydrated grains was read after the time. The HR was determined using the ratio between the final mass and the initial mass of the grains.

Data obtained were subjected to analysis of variance using the F test $(\mathrm{p}<0.05)$ and where necessary, the means were compared using Tukey's test ( $\mathrm{p}<0.05)$, with the aid of the SISVAR software (Ferreira 2011). In the cases of significance by the $\mathrm{F}$ test, the unfolding of the interactions between crops succession versus $\mathrm{N}$ splitting fertilization. 


\section{RESULTS AND DISCUSSION}

Except for HR of grain, crop succession promoted differences in all the technological variables evaluated in common bean (Table 1). Nitrogen splitting fertilization in top-dressing and the interaction between crop succession and $\mathrm{N}$ splitting fertilization promoted differences only for the CPC in the first year and for the cooking time (CT) in the second agricultural year.

Table 1. Sieve yield greater or equal than 12 (SY $\geq 12$ ), crude protein content (CPC), cooking time (CT), and hydration ratio (HR) of common bean grains under succession systems of maize and Urochloa ruziziensis and nitrogen split fertilization in top-dressing.

\begin{tabular}{|c|c|c|c|c|c|c|c|c|}
\hline \multirow{3}{*}{ Treatments } & \multicolumn{2}{|c|}{$S Y \geq 12$} & \multicolumn{2}{|c|}{ CPC } & \multicolumn{2}{|c|}{ CT } & \multicolumn{2}{|c|}{ HR } \\
\hline & 2012 & 2013 & 2012 & 2013 & 2012 & 2013 & 2012 & 2013 \\
\hline & \multicolumn{2}{|c|}{$\%$} & \multicolumn{2}{|c|}{$\mathbf{g} \cdot \mathbf{k g}^{-1}$} & \multicolumn{2}{|c|}{ Min } & \multicolumn{2}{|c|}{ - } \\
\hline \multicolumn{9}{|l|}{ Crops succession (CS) } \\
\hline Maize & $88.3 b$ & $76.9 b$ & 208 & $200 \mathrm{~b}$ & $23 a$ & 21 & 1.99 & 1.99 \\
\hline Maize + U. ruziziensis & $88.2 b$ & $84.2 a$ & 216 & $195 \mathrm{c}$ & $25 \mathrm{~b}$ & 23 & 1.99 & 1.98 \\
\hline U. ruziziensis & $90.8 a$ & $86.1 a$ & 206 & $204 a$ & $25 b$ & 23 & 1.98 & 1.98 \\
\hline CV (\%) & 4.8 & 4.1 & 3.6 & 3.4 & 5.6 & 7.7 & 1.1 & 1.4 \\
\hline MSD (Tukey's $-p<0.05$ ) & 1.93 & 2.34 & 5.22 & 4.72 & 0.94 & 1.18 & 0.01 & 0.02 \\
\hline \multicolumn{9}{|l|}{ Nitrogen splitting (NS) ${ }^{1}$} \\
\hline $00+00+00$ & 89.2 & 82.7 & 207 & 203 & 26 & 24 & 1.98 & 1.99 \\
\hline $00+90+00$ & 87.2 & 82.6 & 218 & 202 & 25 & 22 & 1.99 & 1.98 \\
\hline $30+60+00$ & 86.5 & 80.6 & 205 & 192 & 24 & 22 & 1.99 & 1.99 \\
\hline $60+30+00$ & 90.7 & 83.9 & 205 & 200 & 23 & 22 & 1.99 & 2.00 \\
\hline $30+00+60$ & 90.1 & 81.4 & 201 & 201 & 24 & 22 & 1.98 & 1.98 \\
\hline $60+00+30$ & 88.8 & 82.1 & 204 & 198 & 23 & 23 & 1.99 & 1.97 \\
\hline $00+60+30$ & 89.1 & 83.8 & 220 & 201 & 24 & 21 & 1.99 & 1.98 \\
\hline $45+45+00$ & 89.8 & 81.4 & 211 & 199 & 25 & 22 & 1.98 & 1.98 \\
\hline $00+45+45$ & 89.5 & 83.5 & 210 & 204 & 23 & 23 & 1.99 & 1.99 \\
\hline $45+00+45$ & 89.9 & 82.3 & 220 & 194 & 26 & 21 & 1.99 & 1.98 \\
\hline CV (\%) & 3.5 & 4.8 & 6.2 & 5.2 & 9.8 & 7.6 & 0.8 & 1.0 \\
\hline MSD (Tukey's - $p<0.05$ ) & 4.21 & 5.21 & 17.31 & 13.85 & 3.15 & 2.24 & 0.02 & 0.03 \\
\hline \multicolumn{9}{|l|}{ F test } \\
\hline $\mathrm{CS}$ & $4.71^{\star}$ & $80.66^{\star \star}$ & $17.64^{\star \star}$ & $18.89^{\star \star}$ & $15.05^{\star \star}$ & $19.36^{\star \star}$ & $1.37^{\mathrm{ns}}$ & $0.59^{\text {ns }}$ \\
\hline NS & $2.03^{\text {ns }}$ & $0.95^{\text {ns }}$ & $3.46^{\star \star}$ & $1.56^{\mathrm{ns}}$ & $1.89^{\text {ns }}$ & $2.55^{\star}$ & $1.22^{\mathrm{ns}}$ & $1.45^{\mathrm{ns}}$ \\
\hline $\mathrm{CS} \times \mathrm{NS}$ & $0.39^{\text {ns }}$ & $0.89^{\text {ns }}$ & $4.16^{\star \star}$ & $0.97^{\mathrm{ns}}$ & $1.57^{\mathrm{ns}}$ & $2.08^{\star}$ & $0.42^{\text {ns }}$ & $1.31^{\text {ns }}$ \\
\hline
\end{tabular}

Note. Means followed by distinct letters in the column, within each factor, differ from each other based on Tukey's test $(p<0.05)$. * $p<0.05,{ }^{* *} p<0.01$ and ${ }^{n s}$ not significant, respectively, based on $\mathrm{F}$ test. ${ }^{1} \mathrm{Amount}$ of $\mathrm{N}$ applied in top-dressing on common bean in the phenological stages $\mathrm{V}_{3}$ (formation of the first trifoliate leaf), $V_{4}$ (presence of the third trifoliate leaf), and $R_{5}$ (pre-flowering), respectively.

Regardless of the agricultural year, the sieve yields greater than or equal to 12 ( $\mathrm{SY} \geq 12$ ) of the common bean was higher after succession with $U$. ruziziensis sole. In the second agricultural year, the $S Y \geq 12$ after succession with maize + U. ruziziensis intercropping was similar to that after succession with $U$. ruziziensis sole. In the second year, succession after U. ruziziensis sole promoted higher CPC of common bean. The cooking time of the common bean grain in the first year was 2 min shorter after succession with the maize sole than after succession with the maize $+U$. ruziziensis intercropping and $U$. ruziziensis sole.

Crude protein content in common bean grains was affected by succession and $\mathrm{N}$ splitting, with an interaction occurring in 2012 (Table 2). The contents varied from 189 to $237 \mathrm{~g} \cdot \mathrm{kg}^{-1}$, with emphasis on the $00+60+30$ split after maize sole, $00+45+45$ after U. ruziziensis sole, and V4 $(00+90+00)$ after $U$. ruziziensis sole and intercropping with maize. 
Table 2. Unfolding of the interaction between crop succession versus nitrogen splitting in top-dressing for crude protein content (CPC) in the first year and cooking time (CT) in the second agricultural year.

\begin{tabular}{|c|c|c|c|c|c|c|}
\hline \multirow[b]{2}{*}{ Treatments } & \multicolumn{3}{|c|}{--CPC $\left(\mathbf{g} \cdot \mathrm{kg}^{-1}\right)-2012$} & \multicolumn{3}{|c|}{ - } \\
\hline & Maize & $\begin{array}{c}\text { Maize + } \\
\text { U. ruziziensis }\end{array}$ & U. ruziziensis & Maize & $\begin{array}{c}\text { Maize + } \\
\text { U. ruziziensis }\end{array}$ & U. ruziziensis \\
\hline \multicolumn{7}{|c|}{ Nitrogen splitting ${ }^{(1)}$} \\
\hline $00+00+00$ & 209abAB & $218 a b c A$ & 196abB & $23 a A$ & $25 b B$ & $23 a A$ \\
\hline $00+90+00$ & $194 b B$ & $237 a A$ & $224 a A$ & $20 \mathrm{aA}$ & $23 a b B$ & $23 a A B$ \\
\hline $30+60+00$ & 191bB & 226abA & 197abB & $20 a A$ & $23 a b A B$ & $24 a B$ \\
\hline $60+30+00$ & $214 a b A$ & $210 a b c A B$ & 191bB & $20 \mathrm{aA}$ & $24 a b B$ & $21 a A B$ \\
\hline $30+00+60$ & $200 \mathrm{bAB}$ & $213 a b c A$ & $189 \mathrm{bB}$ & $22 \mathrm{aA}$ & $23 a b A$ & $22 \mathrm{aA}$ \\
\hline $60+00+30$ & $204 \mathrm{bAB}$ & $194 c B$ & $215 a b A$ & $21 a A$ & $22 \mathrm{aA}$ & $25 \mathrm{aB}$ \\
\hline $00+60+30$ & $236 a A$ & 214abcB & 209abB & $19 a A$ & $20 a A B$ & $23 a B$ \\
\hline $45+45+00$ & 214abA & $210 a b c A$ & 210abA & $22 \mathrm{aA}$ & $22 \mathrm{abA}$ & $23 a A$ \\
\hline $00+45+45$ & $203 \mathrm{bA}$ & $204 \mathrm{bcA}$ & $222 a A$ & $21 a A$ & $24 a b B$ & $22 a A B$ \\
\hline $45+00+45$ & 217abAB & 233abA & 211abB & $19 a A$ & $21 a A B$ & $22 a B$ \\
\hline
\end{tabular}

Note. Means followed by distinct letters in the column, within each factor, differ from each other based on Tukey's test. ${ }^{1} \mathrm{Amount}$ of $\mathrm{N}$ applied in top-dressing on common bean in the phenological stages $V_{3}$ (formation of the first trifoliate leaf), $V_{4}$ (presence of the third trifoliate leaf), and $R_{5}$ (pre-flowering), respectively.

In the succession with maize and $U$. ruziziensis in sole crops, the application of $\mathrm{N}$ in top-dressing did not cause differences in cooking time in the second agricultural year (Table 2). In the intercropping succession, the time varied from 20 to $25 \mathrm{~min}$, with emphasis on the $60+00+30 \mathrm{~N}$ split, which reduced the cooking time of common bean compared to those without application of $\mathrm{N}$ in top-dressing.

Correlation analysis between the technological variables evaluated in the two agricultural years (Table 3) shows that there was a direct and significant correlation between the CT with SY $\geq 12$ and CPC and an indirect relationship between CT with HR and HR with $S Y \geq 12$ in the first agricultural year. In the second year, there was a direct and significant correlation only between CPC and HR, while the correlations of SY $\geq 12$ with CPC and CT with SY $\geq 12$ were indirect. However, the correlations were low, at a value below 0.50, except for the correlation between CPC and HR in the second year. In addition, the only significant correlation that was repeated in both years was CT with $S Y \geq 12$, but they showed inverse relationships between years, being direct in the first year and inverse in the second year. This demonstrates the high variability in the qualitative variables of the common bean between agricultural management, harvests, and years of evaluation.

Table 3. Correlation matrix of variables sieve yield greater or equal 12 ( $S Y \geq 12$ ), crude protein content (CPC) of the grains, hydration ratio $(\mathrm{HR})$, and cooking time (CT) of common bean in two agricultural years. Values above the diagonal refer to the first year and values below the diagonal refer to the second agricultural year.

\begin{tabular}{ccccc}
\hline Years 2012/2013 & SY $\geq 12$ & CPC & HR & CT \\
\hline SY $>12$ & - & $-0.07^{\text {ns }}$ & $-0.22^{\star}$ & $0.18^{\star}$ \\
\hline CPC & $-0.34^{\star \star}$ & - & $0.09^{\text {ns }}$ & $0.20^{\star}$ \\
\hline HR & $-0.03^{\text {ns }}$ & $0.53^{\star \star}$ & - & $-0.18^{\star}$ \\
\hline CT & $-0.26^{\star \star}$ & $0.10^{\text {ns }}$ & $-0.03^{\text {ns }}$ & - \\
\hline
\end{tabular}

Note. ${ }^{\text {ns }}$ not significant; * Significant at $5 \%$ probability; ${ }^{* *}$ Significant at $1 \%$ probability.

Regardless of the succession system and the N split, the SY $\geq 12$ of common bean was above the minimum value of $70 \%$ (Table 1) established by packers to characterize large grains and with higher quality for commercialization (Carbonell et al. 2010). However, the higher the $S Y \geq 12$, the greater the financial bonus (agile) that packers can offer on common bean lots. Therefore, the succession of common bean after $U$. ruziziensis sole or intercropping with maize promoted higher technological quality, raising the SY $\geq 12$ and CPC of the grains compared to the succession after maize sole. 
These results can be explained by the high amount of nutrients and straw left in the soil from succession systems after U. ruziziensis cultivation. In the same experimental area and in the same years of this study, Mingotte et al. (2020) evaluated the amount of $\mathrm{N}$ left by the straw of U. ruziziensis sole cropping systems and maize intercropped with U. ruziziensis and observed at least 31 and $60 \%$ greater amount of $\mathrm{N}$ than the maize sole cropping system, respectively. In addition, the straw left by the successions that presented $U$. ruziziensis was greater than that left by the succession with only maize sole. Besides the addition of great amount of $\mathrm{N}$ to the soil, successions that have $U$. ruziziensis leave a great amount of other nutrients in the soil, such as potassium, phosphorus, calcium, magnesium, and sulfur, in addition to reducing soil water loss through evaporation, improving soil fertility, which directly affects the nutrition of common bean (Mingotte et al. 2020; Soratto et al. 2014), and increasing the grain size, as observed in the present study.

The use of $U$. ruziziensis still has other benefits for production systems, since exudates released by the roots of the Urochloa genus can reduce nitrification process and, consequently, reduce losses by N leaching (Gopalakrishnan et al. 2009). This fact is even more important in tropical regions, as in this present study, where some periods of the year have large volume of precipitations that could lead to leaching of N. Thus, areas cultivated with Urochloa tend to have great availability of $\mathrm{N}$ in soils for crops.

In general, crop succession with maize + U. ruziziensis intercropping promoted a higher CPC of common bean in 2012 . Even though the interaction between crop succession systems and N splitting was significant for CPC in 2012, it was observed that the split at the rate of $90 \mathrm{~kg} \cdot \mathrm{ha}^{-1}$ of $\mathrm{N}$ promoted little differences compared to management without $\mathrm{N}$ fertilization in top-dressing $(00+00+00)$, independent of the adopted agricultural management. It appears that CPC was more influenced by crop succession: in the two agricultural years, the highest values of CPC were for the systems with U. ruziziensis, either in intercropping (2012) or in sole cultivation (2013). As the straw of the maize succession system intercropped with $U$. ruziziensis and U. ruziziensis could leave up to 20 and $64 \mathrm{~kg} \cdot \mathrm{ha}^{-1}$ of $\mathrm{N}$ in the soil more than the crop succession system with sole maize (Mingotte et al. 2020), respectively, there is a continuous supply of $\mathrm{N}$ to common bean grown after these systems throughout the crop cycle. In addition, as previously discussed, species of the genus Urochloa can reduce $\mathrm{N}$ losses by leaching into the soil, making more $\mathrm{N}$ available in the soil solution (Gopalakrishnan et al. 2009).

It is observed in the literature that the technological attributes of common bean have high variability due to several factors, such as the production system, agricultural years, cultivars, and sowing seasons (Aires et al. 2019; Flôres et al. 2017; Soratto et al. 2014). This high variability helps to explain the small differences in the common bean quality due to the treatments with $\mathrm{N}$ fertilization and splitting in the present study. The high soil fertility in the experimental area of the present study can also contribute to the small difference in the qualitative attributes of common bean owing to $\mathrm{N}$ rates, presenting high levels of P, exchangeable bases, and supply of $\mathrm{N}$ in high quantities. Coelho et al. (2020) evaluated the extraction of $\mathrm{N}$ by white oats crops in an area close to that of the present study and observed that the soil supplied at least $126 \mathrm{~kg} \cdot \mathrm{ha}^{-1}$ of N to the crop, revealing the high availability of $\mathrm{N}$ in the solution of the soils close to the present study.

In the two agricultural years, the lowest $\mathrm{CT}$ of the common bean grains was obtained after succession with maize sole. On average, the CT of common bean grown in succession with sole maize was 2 min less than the CT of common bean cultivation in succession with sole $U$. ruziziensis and maize $+U$. ruziziensis intercropping. Despite the advantage of succession with sole maize for this variable, it appears that, among the technological characteristics of common bean, CT is one of those that have the least impact on the biological value of the product and its pricing, since the values obtained for all the succession systems are below the maximum value of $30 \mathrm{~min}$ recommended for common bean (Ramalho and Abreu 2006) and fall within the normal cooking resistance classification (21 to $28 \mathrm{~min}$ ), according to the Proctor and Watts scale (1987).

Regardless of the treatments applied to common bean and the agricultural year, HR values were close to 2.00 (Table 1). These values are similar to those observed in the literature, indicating common bean with adequate technological attributes, since low HR values may indicate hard-shelled grains (Flôres et al. 2017; Mingotte et al. 2019). In addition, it also appears that $H R$ values vary little depending on agricultural management (Mingotte et al. 2019).

Variations in the technological attributes of the common bean owing to factors such as crops, cultivars, agricultural years, cultivation, and production systems can be confirmed by the variation and low correlation between the technological variables of the common bean, as shown in Table 3 . Although some correlations were significant $(\mathrm{p}<0.05)$, no correlation 
values above 0.60 were observed in the two agricultural years. In addition, none of the significant correlations have been repeated over the years. This shows that it is difficult and complex to establish relationship between the technological variables of the common bean, demonstrating the high variability of these attributes in relation to the edaphoclimatic conditions that the common bean was subjected to.

Miano et al. (2018), who evaluated the hydration kinetics of grains of common bean cultivars, did not observe high correlations between the nutrient content of the grains and technological variables. According to the authors, the kinetics of grain hydration is complex and can be affected by any change owing to agronomic techniques affecting the technological quality of common bean. Leal et al. (2020) evaluated the relationship between the technological variables of common bean and observed an inverse correlation between cooking time and crude protein content and the variables related to the hydration of the common bean. However, the correlation was not very pronounced and according to the authors, the technological variables were affected by several management, climatic, and genetic factors, and were unlikely to establish relationships between the technological variables of the common bean, as observed in the present study.

\section{CONCLUSION}

Crop succession promotes differences in the technological quality of common bean grains; however, $\mathrm{N}$ splitting fertilization in top-dressing did not affect the grain technological attributes. The highest technological quality of common bean grains was obtained after succession with sole U. ruziziensis, generating large size and crude protein content of grains, followed by the succession of the maize $+U$. ruziziensis, and finally, the succession with sole maize. Thus, crop succession directly affects attributes related to the profitability of producers and biological value of common bean.

\section{AUTHORS' CONTRIBUTION}

Conceptualization: Mingotte F. L. C., Lemos L. B. and Fornasieri Filho D.; Methodology: Mingotte F. L. C., Jardim C. A. and Lemos L. B.; Investigation: Mingotte F. L. C., Yada M. M. and Lemos L. B.; Writing - Original Draft: Mingotte F. L. C. and Coelho A. P.; Writing - Review and Editing: Leal F. T. and Lemos L. B.; Funding Acquisition: Mingotte F. L. C., Lemos L. B.; Resources: Lemos L. B. and Fornasieri Filho D.; Supervision: Lemos L. B. and Fornasieri Filho D.

\section{DATA AVAILABILITY STATEMENT}

All data sets were generated or analyzed in the current study.

\section{FUNDING}

Fundação de Amparo à Pesquisa do Estado de São Paulo

https://doi.org/10.13039/501100001807

Grant No. 2011/07840-9

\section{ACKNOWLEDGMENTS}

We would like to thank the support of the Fazenda de Ensino, Pesquisa e Extensão (FEPE), in the person of Marcelo Scatolin, for their assistance in experiment conducting. 


\section{REFERENCES}

[AOAC] Association of Official Analytical Chemists. (1995). Official methods of analysis of AOAC International. Washington: AOAC.

[CONAB] Companhia Nacional de Abastecimento. (2020). Acompanhamento da safra Brasileira. [Accessed Oct. 10, 2020]. Available at: https://www.conab.gov.br/info-agro/safras

[IBGE] Instituto Brasileiro de Geografia e Estatística. (2020). Pesquisa de orçamentos familiares 2017-2018: Avaliação nutricional da disponibilidade domiciliar de alimentos no Brasil. Rio de Janeiro: IBGE. [Accessed Oct. 10, 2020]. Available at: https://biblioteca.ibge. gov.br/visualizacao/livros/liv101704.pdf

Aires, B. C., Soratto, R. P. and Guidorizzi, F. V. C. (2019). Grain yield and quality of common bean cultivars in response to nitrogen. Científica, 47, 231-238. https://doi.org/10.15361/1984-5529.2019v47n2p231-238

Allen, R. G., Pereira, L. S., Raes, D. and Smith, M. (1998). Crop evapotranspiration: Guidelines for computing crop water requirements [FAO Irrigation and Drainage Paper No. 56]. Rome: FAO.

Alvares, C. A., Stape, J. L., Sentelhas, P. C., Gonçalves, J. L. M. and Sparovek, G. (2013). Köppen’s climate classification map for Brazil. Meteorologische Zeitschrift, 22, 711-728. https://doi.org/10.1127/0941-2948/2013/0507

Ambrosano, E. J., Wutke, E. B., Bulisani, E. A. and Cantarella, H. (1997). Feijão. In B. V. Raij, H. Cantarella, J. A. Quaggio and A. M. Furlani (Eds.), Recomendação de adubação e calagem para o Estado de São Paulo [Boletim Técnico 100] (p. 194-195). Campinas: IAC.

Bataglia, O. C., Furlani, A. M. C., Teixeira, J. P. F., Furlani, P. R. and Gallo, J. R. (1983). Métodos de análise química de plantas [Boletim Técnico 78]. Campinas: IAC.

[BRASIL] Ministério da Agricultura, Pecuária e Abastecimento. (2020) Valor bruto da produção agropecuária (VBP). [Accessed Oct. 10, 2020]. Available at: https://www.gov.br/agricultura/pt-br/assuntos/politica-agricola/valor-bruto-da-producao-agropecuaria-vbp

Carbonell, S. A. M., Chiorato, A. F., Gonçalves, J. G. R., Perina, E. F. and Carvalho, C. R. L. (2010). Tamanho de grão comercial em cultivares de feijoeiro. Ciência Rural, 40, 2067-2073. https://doi.org/10.1590/S0103-84782010005000159

Coelho, A. P., Faria, R. T., Leal, F. T., Barbosa, J. A. and Lemos, L. B. (2020). Biomass and nitrogen accumulation in white oat (Avena sativa L.) under water deficit. Revista Ceres, 67, 001-008. https://doi.org/10.1590/0034-737×202067010001

Fageria, N. K., Ferreira, E. P. B., Melo, L. C. and Knupp, A. M. (2014). Genotypic Differences in Dry Bean Yield and Yield Components as Influenced by Nitrogen Fertilization and Rhizobia. Communications in Soil Science and Plant Analysis, 45, 1583-1604. https://doi.org/ 10.1080/00103624.2013.875204

Fernández, F., Gepts, P. L. and López, M. (1985). Etapas de dessarollo en la planta del frijol. In M. López, F. Fernández and A. van Schoonhoven (Eds.), Frijol: investigación y producción (p.61-78). Cali: CIAT.

Ferreira, D. F. (2011). Sisvar: a computer statistical analysis system. Ciência e Agrotecnologia, 35, 1039-1042. https://doi.org/10.1590/ S1413-70542011000600001

Flôres, J. A., Amaral, C. B., Pinto, C. C., Mingotte, F. L. C. and Lemos, L. B. (2017). Agronomic and qualitative traits of common bean as a function of the straw and nitrogen fertilization. Pesquisa Agropecuária Tropical, 47,195-201. https://doi.org/10.1590/1983-40632016v4743979

Gopalakrishnan, S., Watanabe, T., Pearse, S. J., Ito, O., Hossain, Z. A. K. M. and Subbarao, G. V. (2009). Biological nitrification inhibition by Brachiaria humidicola roots varies with soil type and inhibits nitrifying bacteria, but not other major soil microorganisms. Soil Science and Plant Nutrition, 55, 725-733. https://doi.org/10.1111/j.1747-0765.2009.00398.x

Leal, F. T., Bettiol, J. V. T., Filla, V. A., Coelho, A. P., Mingotte, F. L. C. and Lemos, L. B. (2020). Grain quality of common bean (Phaseolus vulgaris L.) cultivars under low and high nitrogen dose. Revista de la Facultad de Ciências Agrárias UNCuyo. In press. 
Miano, A. C., Saldaña, E., Campestrini, L. H., Chiorato, A. F. and Augusto, P. E. D. (2018). Correlating the properties of different carioca bean cultivars (Phaseolus vulgaris) with their hydration kinetics. Food Research International, 107, 182-194. https://doi.org/10.1016/j. foodres.2018.02.030

Mingotte, F. L. C., Lemos, L. B., Jardim, C. A. and Fornasieri Filho, D. (2019). Crop systems and topdressing nitrogen on grain yield and technological attributes of common bean under no-tillage. Pesquisa Agropecuária Tropical, 49, e54003. https://doi. org/10.1590/1983-40632019v4954003

Mingotte, F. L. C., Jardim, C. A., Yada, M. M., Amaral, C. B., Chiamolera, T. P. L. C., Coelho, A. P., Lemos, L. B. and Fornasieri Filho, D. (2020). Impact of crop management and no-tillage system on grain and straw yield of maize crop. Cereal Research Communications, 48, 399407. https://doi.org/10.1007/s42976-020-00051-y

Nassary, E. K., Baijukya, F. and Ndakidemi, P. A. (2020). Intensification of common bean and maize production through rotations to improve food security for smallholder farmers. Journal of Agriculture and Food Research, 2, 100040. https://doi.org/10.1016/j.jafr.2020.100040

Proctor, J. R. and Watts, B. M. (1987). Development of a modified Mattson Bean Cooker procedure based on sensory panel cookability evaluation. Canadian Institute of Food Science and Technology Journal, 20, 9-14. https://doi.org/10.1016/S0315-5463(87)70662-2

Ramalho, M. A. P. and Abreu, A. F. B. (2006). Cultivares. In C. Vieira, T.J.P. Paula Junior and A. Borém (Eds.), Feijão (p.415-436). Viçosa: UFV. Soratto, R. P., Perez, A. A. G. and Fernandes, A. M. (2014). Age of no-till system and nitrogen management on common bean nutrition and yield. Agronomy Journal, 106, 809-820. https://doi.org/10.2134/agronj13.0439 